\title{
Correction to: Serum substance P: an indicator of disease activity and subclinical inflammation in rheumatoid arthritis
}

\author{
Rosa Elda Barbosa-Cobos ${ }^{1} \cdot$ Gustavo Lugo-Zamudio ${ }^{1}$. Javier Flores-Estrada ${ }^{2} \cdot$ Lizbeth Teresa Becerril-Mendoza $^{1}$. \\ Pedro Rodríguez-Henríquez ${ }^{3} \cdot$ Rubén Torres-González $^{4} \cdot$ Mario Adán Moreno-Eutimio $^{2} \cdot$ Julian Ramirez-Bello $^{2}$. \\ José Moreno ${ }^{2}$
}

Published online: 8 May 2020

(C) International League of Associations for Rheumatology (ILAR) 2020

Correction to: Clinical Rheumatology (2018) 37:901-908 https://doi.org/10.1007/s10067-017-3929-6

Following publication, it was brought to the authors' attention by Dr. Julia Toscano-Garibay that she did not participate as a reviewer of the final version of this manuscript prior to its submission and publication in Clinical Rheumatology. The acknowledgments section of the article has therefore been corrected to avoid any suggestion otherwise and can be found below.

Acknowledgments We acknowledge Dr. Angelica GarciaMartinez, from "Un kilo de ayuda A.C." for in depth advice with statistical analysis. We thank the health professionals and nurses that facilitate our work at the Department of Rheumatology of the Hospital Juárez de México. We are deeply grateful to all patients and controls for their participation in this study. This work was supported by Hospital Juárez de México (HJM 2280/13-A).

The online version of the original article can be found at https://oi.org/ 10.1007/s10067-017-3929-6

Rosa Elda Barbosa-Cobos

rebcob@yahoo.com

1 Department of Rheumatology, Hospital Juárez de México, Av. Instituto Politécnico Nacional 5160, Delegación: Magdalena de las Salinas, 17760 Mexico City, Mexico

2 Research Unit, Hospital Juárez de México, Mexico City, Mexico

3 Department of Rheumatology, Hospital Manuel Gea González, Mexico City, Mexico

4 Hospital de Traumatología y Ortopedia, UMAE 'Magdalena de las Salinas' IMSS, Mexico City, Mexico 